\title{
MASALAH KEJAHATAN \\ DAN PEMELIHARAAN ALLAH
}

\author{
Herny Kongguasa
}

\begin{abstract}
Abstrak
Masalah Kejafiatan yang mengakibatkan penderitaan adalah suatu misteri 6agi manusia. Namun Alkitab menyatakan adanya pemelifaraan Allah di tengah-tengah fakta adanya Kejahatan dan penferitaan.
\end{abstract}

\section{PENDAHULUAN}

\section{Latar Belakang}

Hidup ini tidak lepas dari kejahatan dan penderitaan. Berita-berita yang diterima setiap hari (baik dari radio, televisi, koran, majalah, dll.), selalu berbicara mengenai hal ini. Alkitab juga berbicara mengenai problema kejahatan dan penderitaan. Kitab Ayub mencatatat dengan jelas realita problema ini. Dalam kitab Ayub, adanya realita kejahatan dan penderitaan menjadi pokok diskusi dari Ayub, istrinya dan teman-temannya. Dalam kitab Ayub, dapat terlihat bahwa topik mengenai kejahatan dan penderitaan merupakan topik mendasar dari kitab ini.

Di zaman sekarang, problema kejahatan dapat dilihat dalam peristiwa pengeboman gedung WTC di New York (11 September 2001), disusul dengan pengeboman yang terjadi di Bali, tidak lama setelah itu terjadi lagi hal serupa di Hotel JW Marriot Jakarta, berikutnya 09 September 2004 bom kembali meledak di depan kantor Kedubes Australia,' Jakarta. Peristiwa lain berupa bencana alam, seperti banjir di Pulau Jawa, gunung meletus di Sulawesi dan kebakaran hutan di Kalimantan. Semua realita ini hanyalah beberapa dari banyaknya problema kejahatan yang dapat dijumpai dalam dunia ini.

Problema kejahatan akan terus ditemui di sepanjang zaman. Sebagai contoh dari zaman Ayub, masalah yang sama yaitu kejahatan dan penderitaan tetap dijumpai pada masa kini. Problema ini telah ada dan akan terus ada.

Jadi, dapatlah dikatakan bahwa problema kejahatan telah menjadi problema yang universal sifatnya, maksudnya adalah bahwa problema kejahatan merupakan suatu problema yang ditemui sepanjang zaman (sejak manusia ada hingga akhir dunia ini), 
terjadi pada semua orang (baik yang percaya maupun yang tidak percaya), bagi semua latar belakang pendidikan dan bagi semua usia (baik orang dewasa maupun anak-anak). Singkatnya, problema kejahatan dialami oleh seluruh umat manusia di seluruh penjuru bumi.

Peristiwa-peristiwa kejahatan ini bisa menimbulkan berbagai pertanyaan, salah satunya seperti "Apakah Allah tidak mengasihi manusia sehingga Allah tega membiarkan hal itu terjadi?" Pertanyaan seperti ini, merupakan bentuk sederhana dari problema kejahatan.

Bila ditelusuri, pertanyaan demikian selalu merupakan pertanyaan manusia sebagai tanggapan terhadap problema kejahatan. Seperti yang ditulis Frame:

"Siapa di antara kita yang belum pernah berteriak "Mengapa Tuhan?" pada saat kita mengalami tragedi di dalam pengalaman kita?" Kita secara sederhana merasakan adanya suatu ketidakcocokan yang sangat buruk antara pengalaman kita dan keyakinan kita tentang Allah. Jeritan hati kita mungkin sama dengan jeritan penderitaan, sebuah jeritan minta tolong, sebuah jeritan keragu-raguan yang mempertanyakan presuposisi-presuposisi terdalam milik kita sendiri." ${ }^{1}$

Ayub sebagai manusia yang tengah mengalami penderitaan pun berseru, mengapa Allah mengijinkan penderitaannya? (Ayb. 10:1-22). Bahwa adalah lebih baik bila ia tidak dilahirkan ke dunia (Ayb. 3:11), bahkan istrinya sendiri menyuruhnya untuk mengutuki Allah (Ayb. 2:10).

Selain itu, masalah kejahatan sering dipakai oleh para penganut Atheis untuk menyangkali keberadaan Allah. Bahwa dengan adanya kejahatan dan penderitaan di dalam dunia, berarti Allah tidak ada.

Jelaslah bahwa problema kejahatan yang sifatnya universal ini, merupakan tantangan terbesar yang terus dihadapi orang percaya, baik sebagai tantangan bagi dirinya sendiri maupun tantangan terhadap imannya kepada Allah. Karenanya, problema kejahatan ini menuntut suatu jawaban dari sudut pandang iman Kristen.

\section{Batasan Penulisan}

Tak dapat dihindari, berbicara mengenai problema kejahatan akan membawa kepada masalah:

Pertama, setiap kejahatan menyangkal adanya Allah yang Mahabaik. 
Kedua, adanya kejahatan menyangkal adanya Allah yang Mahakuasa.

Keduanya membawa kepada kesimpulan bahwa Allah itu tidak ada, seperti yang dipercayai oleh kaum Atheis. Akan tetapi, karena tulisan ini memberi porsi kepada masalah kejahatan dan providensi Allah (pemeliharaan Allah), maka hubungan kejahatan dan kesimpulan "Allah tidak ada" tidak akan dibahas dalam tulisan ini, sekalipun hal tersebut merupakan salah satu hal penting bila berbicara tentang kejahatan.

\section{Pokok Masalah}

Seperti yang telah dikatakan di atas, masalah kejahatan mengundang bạnyak pertanyaan sebagai tanggapan terhadap problema tersebut. Maka dalam tulisan ini, penulis akan membahas: Mengapa kejahatan dan penderitaan itu ada? Bagaimanakah hubungan pemeliharaan Allah dengan kejahatan dan penderitaan? Apakah maksud atau tujuan Allah di dalam kejahatan dan penderitaan itu? Bagaimanakah orang percaya seharusnya bersikap dalam memandang kejahatan dan penderitaan itu?

Tulisan ini, walaupun tidak memuat seluruh jawaban yang pernah ada dalam sejarah terhadap masalah kejahatan dan penderitaan, namun merupakan penyelesaianpenyelesaian yang penulis anggap sesuai dengan konsep penulis terhadap firman Tuhan.

\section{Masalah Kejahatan (The Problem of Evil)}

\section{Pengertian Istilah}

Istilah kejahatan atau "The evil", biasanya c.imengerti sebagai lawan dari kebaikan, atau dalam kamus Inggris-Indonesia diartikan sebagai kemalangan. ${ }^{2}$

Menurut R C. Sproul,

Istilah kejahatan seringkali didefenisikan dengan istilah-istilah Latin "Negatio" dan

"Privatio". Negatio mengacu kepada cara-cara negatif yang dipakai untuk mendefenisikan kejahatan. Misalnya, pemakaian dalam istilah ketidakbenaran, ketidaksalehan, tidak etis, bahkan anti Kristus. Maknanya bergantung pada pemahaman awal akar kata positif itu sendiri, contonya: untuk memahami istilah ketidaksalehan, seseorang harus memahami arti dari kata saleh terlebih dahulu. Pengertian tentang kejahatan bergantung dan berasal dari pengertian tentang kebaikan. Kejahatan dibahas sebagai negatifnya kebaikan. ${ }^{3}$

Jadi, bertolak dari istilah "Negatio", kejahatan dapat dilihat sebagai kontras atau negatifnya kebaikan, atau lawan dari kebaikan. Bisa juga dikatakan, ketika kita berbicara tentang kejahatan, kita cenderung memakai istilah-istilah negatif.

Sedangkan istilah "Privatio" (kekurangan) mengandung pengertian absennya atau kurangnya kebaikan yang positif. Misalnya, Katekismus Westminster memberikan 
defenisi dosa sebagai kurangnya persesuaian dengan hukum atau kegagalan dalam hal kepatuhan. Dosa adalah kurangnya kepatuhan, suatu pelanggaran hukum. ${ }^{4}$

Akan tetapi, kedua istilah ini dapat menyebabkan orang beranggapan bahwa kejahatan itu tidak ada, karena kejahatan hanya diartikan sebagai absennya atau kurangnya sesuatu yang positif. Jadi, kejahatan bisa saja bukan apa-apa.

Karena itu, dari Reformasi Prostestan muncul istilah "Actuosa" untuk menambah keterangan tentang sifat dosa. Jadi, kejahatan didefenisikan sebagai privatio dan actuosa. Ini berarti bahwa meskipun kejahatan itu bergantung, namun nyata dan berkuasa. ${ }^{5}$ Kejahatan adalah suatu realitas yang nyata dan mengerikan, dan kejahatan menguasai kehidupan manusia pada umumnya.

Hal lain yang perlu diperhatikan dalam sejarah penyelesaian problema kejahatan, terdapat suatu upaya pembagian terhadap kejahatan itu sendiri.

Oleh seorang filosof Gottfried Leibniz ${ }^{6}$, kejahatan itu dibedakan dalam tiga bagian, yaitu kejahatan moral, kejahatan fisik dan kejahatan metafisik. Kejahatan moral sebagai tindakan sukarela yang dilakukan oleh ciptaan yang memiliki kemampuan melakukan kejahatan moral. Kejahatan fisik (alamiah) diartikan sebagai penderitaan fisik yang diakibatkan oleh penyakit, luka atau malapetaka alam seperti gempa bumi. Sedang kejahatan metafisik ${ }^{7}$, berhubungan dengan keterbatasan dari makhluk ciptaan yang terbatas. Dan dari kejahatan inilah muncul kejahatan moral dan kejahatan fisik (alamiah).

Dalam tulisan ini, istilah kejahatan moral dan kejahatan alamiah akan dipakai dalam pengertian dasar yang sama dengan pengertian yang diberikan oleh Leibniz. Dan istilah "Kejahatan" dalam tulisan ini, mencakup kejahatan moral dan alamiah. Selain itu, perlu diperhatikan bahwa ketika istilah dosa dipakai dalam tulisan ini, istilah tersebut diidentikkan dengan istilah kejahatan moral. Dari sinilah muncul istilah penderitaan, yaitu perasaan yang dialami oleh seseorang sebagai akibat mengalami suatu tindakan kejahatan.

Sebelum melihat lebih jauh, perlu diperhatikan hubungan kejahatan dan problema kejahatan itu sendiri. Jikalau diselidiki dengan lebih seksama, ternyata tidak semua kejahatan menghasilkan problema kejahatan. Problema itu akan muncul ketika manusia mengalami penderitaan yang merupakan akibat dari kejahatan. Jikalau penderitaan itu tidak muncul atau tidak dirasakan oleh manusia, maka problema kejahatan tidak akan dipertanyakan.

Misalnya, jikalau gempa bumi terjadi di satu pulau yang tidak berpenduduk maka tentunya tidak ada reaksi terhadap kejahatan tersebut. Demikian juga banjir Sungai 
Nil, justru dipandang baik oleh orang Mesir untuk kesuburan tanah. Gempa dan banjir Sungai Nil tetap merupakan bagian dari kejahatan alamiah, namun kejahatan tersebut tidak sampai menimbulkan problema kejahatan.

Dari fakta ini, terlihat bahwa tidak selalu kejahatan mendatangkan problem bagi manusia. Hal ini bergantung apakah kejahatan tersebut mendatangkan penderitaan bagi manusia atau tidak. Ketika kejahatan tersebut mendatangkan penderitaan, maka disebut sebagai problema kejahatan.

\section{Kejahatan dan Penilaian Moral}

Untuk lebih memahami tentang kejahatan, ada baiknya istilah ini ditinjau melalui penilaian moral. Secara sederhana, moral berbicara tentang baik buruk yang diterima umum mengenai perbuatan, sikap, kewajiban, dsb ${ }^{8}$. Menurut John M. Frame', "Bagaimanapun juga nilai-nilai moral agak aneh, kita tidak dapat melihat mereka, mendengar mereka, atau merasakan mereka. Tetapi kita tidak dapat meragukan eksistensi mereka."

Ditambahkan lagi,

Walaupun benar dan salah, tidak dapat langsung dilihat atau didengar, mereka timbul dari pengalaman. Tingkah laku yang "benar" cenderung dihargai, tetapi tingkah laku yang "salah" cenderung membawa kepada konsekuensi-konsekuensi yang buruk. Maka, kita membangun konsep tentang benar dan salah berdasarkan konsekuensi-konsekuensi.

Ini berarti, akibat yang ditimbulkan oleh suatu perbuatan yang dilakukan, menjadi patokan atau tolok ukur untuk menilai suatu perbuatan apakah baik atau jahat. Sekalipun "sebab" tidak selalu seragam dengan "akibat"-nya. Hal ini oleh David Hume seperti yang dikutip Frame menunjukkan: "x membawa konsekuensi-konsekuensi baik", tidak secara logis berarti bahwa " $x$ baik secara moralitas"10. Namun " $x$ " bisa dianggap baik, oleh karena konsekuensi yang dihasilkannya. Seperti pemazmur yang sering memprotes, yang jahat kadang-kadang makmur, yang benar kadang-kadang miskin (Maz. 37). Seseorang bisa mengambil kesimpulan bahwa seseorang seharusnya jahat (berdasarkan konsekuensi yang dihasilkannya); maka kejahatan tidak akan jahat, tetapi baik.

Dengan konsep seperti ini, maka nilai-nilai moral bisa merupakan perasaanperasaan subjektif individu. Bahkan bagi Frame, ${ }^{11}$ nilai moral "Bisa juga merupakan perasaan-perasaan subjektif yang dibagikan dalam kebudayaan yang diberikan dan 
diturunkan dari generasi ke generasi". Oleh Kamus Besar Bahasa Indonesia ${ }^{12}$, memperjelasnya dengan pengertian sebagai nilai mengenai benar dan salah yang dimuat suatu golongan atau masyarakat. Jadi, bisa dikatakan, suatu perbuatan adalah benar atau salah hanya karena menjadi "kebiasaan" turun-temurun atau merupakan nilainilai subjektif secara budaya. Waktu seseorang mendengar tentang kanibalisme pada suku terpencil, respon seseorang adalah "itu jahat". Tetapi bagi suku setempat, kanibalisme merupakan hal yang biasa bahkan dibenarkan. Bagi Saulus, membunuh orang-orang percaya merupakan kebenaran yang diyakininya (Kis. 8-9). Tetapi bagi orang percaya, ini dianggap tidak bermoral dan jahat. Namun, bisakah Saulus dihakimi berdasarkan apa yang diyakininya menurut penilaian moral? Oleh karena itu bagi Frame ${ }^{13}$ :

Jika nilai moral hanya subjektif, kita akan bebas untuk percaya dan mempertahankan apa saja yang kita sukai tidak dibatasi oleh bukti, logika atau wahyu. Jika nilai-nilai moral hanya subjektif, kita tidak dapat membuat perhitungan moral sama sekali terhadap seseorang yang menolak untuk memperhatikan fakta-fakta dan yang akibatnya ia hidup dalam dunia mimpi yang diciptakannya sendiri.

K. Bertens menyebut nilai moral seperti ini sebagai relativisme moral ${ }^{14}$. Memang sedikit ekstrim untuk mengatakan bahwa setiap kebudayaan mempunyai kebenaran etis sendiri-sendiri, sehingga apa yang baik serta terpuji di tempat A bisa dianggap jahat serta tercela di tempat B. Akibatnya, kita hanya perlu memperhatikan kaidah-kaidah moral suatu masyarakat untuk mengukur baik tidaknya pilaku manusia dalam masyarakat itu. ${ }^{15}$ Ini berarti, penilaian benar tidaknya suatu perbuatan bisa berbeda antara satu tempat dengan tempat yang lain.

Oleh karena adanya relativisme moral dalam masyarakat, maka dibutuhkan suatu pedoman, standar atau tolok ukur mutlak dan obyektif ${ }^{16}$ untuk menilai baik tidaknya suatu perbuatan.

Sampai di sini, kesimpulan awal adalah bahwa penilaian moral tidak bisa dijadikan dasar, pedoman atau tolok ukur untuk menilai baik atau jahatnya suatu tindakan. Jikalau demikian, apakah yang seharusnya dipakai sebagai pedoman, standar atau tolok ukur untuk menilai baik atau jahatnya suatu tindakan? 


\section{Kejahatan dan Kebaikan Sebagai Sifat Allah}

Seperti telah dikatakan sebelumnya bahwa istilah kejahatan dan kebaikan menuntut suatu norma atau standar penilaian yang dapat mengevaluasi apakah sesuatu hal itu baik atau jahat. Standar penilaian ini bisa berupa berbagai bentuk. Misalnya: sesuatu hal itu baik atau jahat jikalau hal tersebut melayani kepentingan banyak orang dan jahat jikalau melayani kepentingan pribadi. Kepentingan komunitas menjadi standar penilaian dari baik dan jahat. Dalam kasus ini, kepentingan komunitas jauh lebih penting dari kebutuhan pribadi, atau yang menjadi standarnya adalah pengorbanan diri. Sehingga orang yang baik adalah orang yang mengorbankan dirinya bagi orang lain, sedang orang jahat adalah orang yang mengambil keuntungan dari orang lain bagi kepentingannya sendiri.

C. S. Lewis mengatakan, "What seems to us good may therefore not be good in His eyes, and what seems to us evil may not evil". ${ }^{17}$. A. Van De Beek menjelaskan bahwa, "God himself is the authority by whom our goodness or "badness" is measured."18

Allah adalah sumber kebaikan dan kebaikan itu sendiri. Segala hal yang selaras dengan sifat dan kehendak Allah, itulah kebaikan. Kebaikan itu adalah kehendak Allah sendiri. Van De Beek mengatakan "The good is not something that stands bay itself, but that which conforms to will of God. Good is what God will. By saying that, one at the same says that God cannot will evil. The moment God wills anything it is good."19

Apa yang dikerjakan Allah adalah baik adanya. Konsep ini harus tertanam dalam diri setiap orang percaya. Baik manusia dapat mengerti atau tidak, apa yang dilakukan Allah adalah baik, karena Dia-lah kebaikan itu sendiri. Paulus mengingatkan orang percaya agar tidak membantah akan apa yang dikerjakan oleh Allah (Rm. 8:28). Morris menegaskan hal ini, "We ourselves do not establish the standards of what is right. Only the Cretor of all reality can do that. We need to seattle it in our mind and hearts, whether we understand it or not, that whatever God does is, by definition, right." 20

Satu-satunya standar kebaikan adalah Allah sendiri. Apapun yang dikerjakan Allah itulah kebaikan. Konsep orang percaya mengenai kebaikan hanya didasarkan pada wahyu Allah sendiri, dan bukan pada hal lain.

Jadi, norma atau standar penilaian yang dapat mengevaluasi apakah sesuatu hal itu baik atau jahat (mutlak dan objektif) adalah perintah Allah sendiri. Atau dengan kata lain, kejahatan adalah segala sesuatu yang bertentangan dengan diri Allah dan firman-Nya.

Dengan demikian, tindakan kejahatan adalah tindakan-tindakan yang melanggar atau melawan firman atau perintah Allah, dan tindakan yang melanggar firman Allah 
disebut sebagai "kejahatan moral", yaitu pelanggaran yang dilakukan oleh oknum bermoral, dalam hal ini adalah manusia.

\section{Kejahatan dan Dosa Manusia}

\section{Dosa}

Ketika berbicara mengenai fakta adanya kejahatan dan penderitaan di dalam dunia, maka tidak bisa tidak, hal itu akan berkaitan dengan keberadaan dosa. Karena dosa lah manusia mengenal apa itu kejahatan dan pada akhirnya mengenal apa itu penderitaan. Dengan kata lain, sumber dari kejahatan dan penderitaan yang dialami saat ini bermuara dari dosa.

\section{Pengertian Dosa}

Dalam Perjanjian Lama, ada beberapa istilah yang dipakai untuk menunjuk kepada dosa. Hatta'th yang berarti "menyimpang dari jalan yang benar" atau "tindakan yang tidak kena pada sasaran'. Awon yang berati "serong", "berliku-liku", "kekurangan integritas dan kejujuran", atau "meleset dari lintasan yang ditunjuk". Kata Rasa (fasik, menyimpang dari hukum secara jahat dan penuh kesalahan) dan Asam (bersalah) keduanya menunjuk kepada keadaan berada dalam dosa dan patut dihukum. Kata yang lain adalah Pesa, menunjuk kepada tindakan pemberontakan, penolakan untuk tunduk di bawah otoritas yang benar, suatu pelanggaran yang nyata terhadap hukum, dan pelanggaran atas perjanjian yang dibuat. ${ }^{21}$

Sedangkan di dalam Perjanjian Baru, digunakan istilah Hamartia, Adikia, Parabasis, Paraptoma, Anomia, Paranomia; dan semuanya ini menunjuk pada pengertian yang sama seperti dalam Perjanjian Lama. ${ }^{22}$ Dari apa yang Alkitab nyatakan, jelas bahwa dosa lebih dilihat sebagai suatu permusuhan aktif yang dilakukan manusia terhadap Tuhan dan merupakan pelanggaran aktif terhadap segala hukum-Nya.

Bila dihubungkan dengan pengertian kejahatan, maka dapat disimpulkan bahwa dosa identik dengan kejahatan moral. Namun, dosa tidak identik dengan kejahatan, karena disamping kejahatan moral ada kejahatan alamiah. Sekalipun kejahatan alamiah merupakan akibat tidak langsung dari kejahatan moral manusia. Kejahatan lebih luas sifatnya. Berkhof mengingatkan bahwa "Dosa tidak identik dengan kejahatan. Tidak semua kejahatan adalah dosa. Dosa tidak boleh dikacaukan dengan pengertian kejahatan 
fisik, yang mencelakakan dan menimbulkan bencana". ${ }^{23}$ Dosa lebih menunjuk pada pengertian dari kejahatan moral, dan kejahatan alamiah lebih kepada akibat dari kejahatan moral. $^{24}$

Ketika berbicara mengenai dosa, perlu dilihat dalam konteks hubungannya dengan Allah yang kudus. Tidak mungkin untuk memiliki konsep yang benar tentang dosa tanpa melihatnya dalam hubungan dengan Allah dan kehendak-Nya. Berkhof menegaskan hal ini ketika memberikan penilaian terhadap teori-teori filsafat yang ada berkenaan dengan natur kejahatan. ${ }^{25}$

Berkhof mengatakan,

Kelemahan yang sangat radikal dari semua teori ini adalah karena mereka berusaha mendefenisikan dosa tanpa mempertimbangkan bahwa dosa secara esensial adalah melarikan diri dari Allah, permusuhan dengan Allah dan pelanggaran terhadap hukum Allah. Dosa harus senantiasa didefenisikan dalam pengertian hubungan manusia dengan Allah dan kehendak-Nya sebagaimana dinyatakan dalam hukum moral. $^{26}$

Jadi, dapatlah didefenisikan bahwa dosa adalah pemisahan dari Allah, melawan Allah, membenci Allah, dan ini terungkap di dalam pelanggaran atas hukum Allah secara terus menerus (secara aktif); baik dalam pikiran, perkataan dan perbuatan. Hal ini ditegaskan dalam beberapa ayat Alkitab: Roma 1:32; 2:12-14; 4:15; Yakobus 2:9; I Yohanes 3:4.

\section{Asal Mula Dosa}

Berbicara mengenai asal mula dosa, tidak bisa tidak akan kembali pada pasalpasal awal kitab Kejadian, khususnya pasal 3.

"Larangan" Allah (Kej. 3:3) sebagai perintah kepada Adam (untuk menguji ketaatan Adam; bahwa ketidaktaatannya terhadap larangan tersebut mengakibatkan dosa, maut dan penghukuman masuk ke dalam dunia..${ }^{27}$ ), memang memberikan peluang kemungkinan Adam jatuh ke dalam dosa, tetapi kenyataan ini tidak boleh ditafsirkan bahwa Allah adalah penyebab dosa. Allah bukanlah pembuat yang bertanggung jawab atas terjadinya dosa. Bila konsisten dengan defenisi kejahatan dan defenisi dosa seperti yang telah diuraikan sebelumnya, maka jelas bahwa Allah bukan pencipta dosa karena dosa adalah melawan hukum Allah, bagaimana mungkin Allah melawan hukum-Nya sendiri.

Jadi, kejatuhan merupakan peristiwa yang sungguh-sungguh terjadi dalam sejarah 1ımat manusia. ${ }^{28}$ Demikian pula, Allah tidak boleh dianggap sebagai pencipta dosa. 
Berkhof dengan tepat mengatakan bahwa "... jelas merupakan suatu penghujatan jika kita mengatakan bahwa Allah adalah pembuat dosa." ${ }^{\prime 29}$ Ini adalah dasar pertama sebelum lebih lanjut menelusuri perkataan Alkitab berkenaan dengan asal mula dosa.

Menurut Hoekema, "... sebelum kita berfokus pada narasi Kejadian tentang Kejatuhan yang mencatat asal usul dosa di dalam hidup manusia, kita harus ingat bahwa dosa ada sebelum manusia jatuh, yaitu di dalam kejatuhan malaikat. "130

Alkitab memang tidak pernah mencatat kapan malaikat jatuh. Dalam Yohanes 8:44, Yesus menyebut iblis sebagai pembunuh manusia sejak semula (kat'arches). Istilah kat'arches berarti sejak awal permulaan sejarah manusia, dan Yohanes mengatakan dalam I Yohanes 3:8, bahwa iblis berdosa dari mulanya. ${ }^{31}$ Jadi secara kronologis, dapat dikatakan bahwa malaikat jatuh pada waktu setelah penciptaan yang dilakukan Allah dan sebelum kejatuhan manusia pertama.

Dalam I Timotius 3:6 dan Yudas 6, dikatakan bahwa malaikat yang jatuh dalam dosa "tidak taat pada batas-batas kekuasaan mereka, tetapi meninggalkan tempat kediaman mereka". Dapat disimpulkan, bahwa dosa dari malaikat yang jatuh itu adalah dosa kesombongan, ingin menjadi seperti Allah dalam kuasa dan otoritas. Jadi, akar dosa mereka adalah kesombongan yang mengakibatkan pemberontakan terhadap Allah.

Menurut Hoekema ${ }^{32}$,

Yang signifikan di sini, dosa tidak berasal dari dunia manusia melainkan dari dunia roh. Roh-roh ini tidak dicobai unttik berdosa oleh satu kuasa atau kekuatan di luar diri mereka; mereka jatuh oleh diri mereka sendiri. Ketika ia [iblis] berdusta, ia berkata "atas kehendaknya [naturnya] sendiri" (Yoh. 8:44; Yunani: ek ton idion). Dengan kata lain, iblis, pemimpin para malaikat yang jatuh, berdusta dari dirinya sendiri.

Bekhof menegaskan, "Apabila keinginan untuk menjadi seperti Allah adalah pencobaan yang jelas mereka alami, ini juga akan menjelaskan mengapa iblis mencobai manusia dalam hal serupa." ${ }^{\prime 33}$ Satu hal yang pasti adalah peristiwa kejatuhan manusia ke dalam dosa didahului oleh peristiwa kejatuhan malaikat.

\section{Munculnya Dosa dalam Kehidupan Manusia}

Alkitab mencatat bahwa dosa mulai muncul dalam sejarah kehidupan umat manusia dimulai dengan peristiwa pelanggaran Adam di Taman Eden. Dalam hal ini, Hoekema menulis," Adam dan Hawa dicobai di Taman Eden oleh makhluk yang disebut ular (Kej. 3:1). Ular tersebut menjadi alat atau "juru bicara setan..."34 Kemudian Adam kalah dalam menghadapi pencobaan ini dan melakukan dosa yang pertama, dengan cara makan buah yang dilarang itu. ${ }^{35}$ Peristiwa ini merupakan satu tindakan kejahatan yang dengan sengaja dipilih manusia can akibatnya membawa penderitaan besar bagi 
dirinya. Jadi, dosa merupakan akibat dari satu pilihan bebas, tetapi jahat dari manusia. Jahat karena melanggar hukum Allah, suatu tindakan yang secara sadar dilakukan oleh manusia. Kenyataan ini merupakan ajaran yang jelas disebut oleh firman Tuhan dalam Kejadian 3:1-6; Yesaya 48:8; Roma 1:18-32; I Yohanes 3:4. Tindakan secara sadar dilakukan oleh manusia inilah yang mengharuskan manusia bertanggungjawab atas dosa, dan menerima penghukumannya.

\section{Hukuman dan Jangkauan Dosa}

Hoekema menulis: "Sebagai akibat kejatuhan, dosa telah menjadi universal; terkecuali Yesus Kristus, tak seorang pun manusia yang pernah hidup di bumi ini bebas dari dosa... Alkitab dengan jelas mengajarkan universalitas dosa - di dalam arti pemberontakan terhadap perintah Allah."36 Beberapa ayat Alkitab jelas berbicara mengenai universalitas dosa ini, I Raja-raja 8:46; Ayub 14:4; Mazmur 143:2; Pengkhotbah 7:20; Yohanes 3:3; Roma 3:23; Yakobus 3:2; Yohanes 1:8,10; dll.

Menurut Louis Berkhof, ada dua elemen dari dosa asal. Kedua elemen itu adalah: ${ }^{37}$ (1) Kesalahan asal. ${ }^{38}$ (2) Kekotoran asal..$^{39}$

Istilah "kesalahan asal" dan "kekotoran asal" juga saling berkaitan erat. Karena adanya "kekotoran asal" (jangkauan yang universal) menyebabkan "kesalahan asal" (hukuman yang universal harus terjadi). Keterkaitan hal ini dijelaskan dengan sangat baik oleh Van de Beek:40

Suffering is a universal experience. Throughout the world, to its most distant corner, there is suffering. There has been no time, no year, no day in history in which people did not suffer. The universality of suffering points to the universality of human guilt. Throughout the world, to its most distant corner, there is human guilt. There is no period, year, or day in history in which people did not sin. The Heidelberg Catechism rightly says that that we daily increase our debt (Answer 13).

Pada waktu Allah memberikan larangan-Nya kepada Adam; Allah memberitahukan juga kepada Adam akibat yang akan terjadi bila ia melanggar larangan tersebut. Akibat pelanggaran itu adalah kematian bagi Adam (Kej. 2:17). Oleh Berkhof, kematian yang dimaksud itu mencakup: ${ }^{41}$

\section{A. Kematian Rohani}

Dosa memisahkan manusia dari Allah dan ini berarti maut, sebab hanya di dalam persekutuan dengan Allah, manusia dapat sungguh-sungguh hidup. Kematian rohani menjadi bagian yang pasti dimiliki oleh seorang manusia ketika mulai ada dalam dunia ini. 


\section{B. Penderitaan-penderitaan dalam hidup}

Penderitaan-penderitaan dalam hidup sebagai akibat munculnya dosa dalam dunia, juga tercakup dalam hukuman dosa. Dosa membawa kekacauan dalam seluruh hidup manusia.

Kekuatan-kekuatan destruktif seringkali keluar dalam gempa bumi, angin topan, letusan gunung berapi, banjir dan bencana yang membawa kesusahan tak terkatakan bagi manusia. Dan jaman ini banyak orang tidak melihat tangan Tuhan dalam bencanabencana yang terjadi, serta tidak melihatnya sebagai hukuman atas dosa. Hal ini tidak berarti bahwa bencana tersebut ditafsirkan sebagai hukuman khusus bagi dosa-dosa khusus yang dilakukan orang-orang di daerah yang terkena bencana itu.

Kita senantiasa perlu mengingat akan adanya tanggung jawab kolektif dan ada alasan yang cukup bagi Tuhan untuk mengadakan penghukuman bagi kota, daerah atau bangsa tertentu (seperti Sodom dan Gomora), dengan bencana yang mengerikan. Dan agak mengherankan, mengapa Allah tidak lebih sering mengadakan hal tersebut dalam murka-Nya dan dalam ketidaksukaan-Nya. Ini menunjukkan fakta anugerah Allah yang besar bagi manusia.

C. Kematian Jasmani

Terpisahnya tubuh dan jiwa juga merupakan bagian dari hukuman atas dosa. Kita bisa menemukan hal ini dalam kehidupan sehari-hari dan juga dalam penyataan Alkitab (Kej. 3:19; Rm. 5:12-21; I Kor. 15:12-23).

\section{Kematian Kekal}

Kematian ini boleh dianggap sebagai titik puncak dan kelengkapan kematian rohani. Suatu kematian yang akan terjadi bagi mereka yang tidak percaya kepada Anak Tunggal Allah dan yang akan terjadi pada akhir dunia kelak.

Jadi, segala kejahatan dan penderitaan mulai masuk ke dalam dunia disebabkan oleh karena kejatuhan manusia yang pertama. Beek dengan tepat menulis "By $\sin$, the door of the world was opened to all shorts misery. Or should we say, because the door of the world was somehow open to evil, sin and all other misery entered it?"42 Adanya dosa yang universal mengakibatkan penghukuman yang universal.

\section{Dosa dan Kejahatan Moral}

Pada bagian "Defenisi Dosa", telah disebutkan bahwa dosa adalah kejahatan moral. Alkitab menegaskan bahwa kejahatan moral yang ada dalam dunia jelas adalah dosa, yaitu pelanggaran terhadap hukum Allah. Bisa dikatakan, dosa pertama oleh Adam merupakan kejahatan mora' yang ditujukan langsung terhadap Allah, yang kemudian 
diikuti oleh berbagai kejahatan moral lainnya (sebagai fakta, kejatuhan Adam diikuti dengan terjadinya pembunuhan yang pertama oleh Kain terhadap Habel).

Karena dosa pertama Adam, maka jangkauan dosa bersifat universal dengan kata lain, seluruh manusia yang lahir dalam dunia berada dalam natur yang berdosa. Natur yang berdosa inilah oleh McArthur diistilahkan sebagai “...'rusak moral secara total'... dalam arti tidak sanggup melakukan apa pun yang menyenangkan hati Allah...tidak mempunyai kemampuan untuk melakukan perkara yang baik secara rohani ataupun mengerti bagaimana bisa diselamatkan." 43

Jadi, natur berdosa inilah yang terekspresi dalam tindakan-tindakan berdosa. Manusia tidak mungkin dapat melakukan suatu perbuatan baik di hadapan Allah. Semua perbuatan baik manusia tidak ada nilainya di hadapan Allah (Yes. 64:6). Bisa dikatakan, kejahatan-kejahatan moral yang terus terjadi tidak bisa terlepas atau merupakan satu mata rantai dari dosa pertama manusia.

\section{Dosa dan Kejahatan Alamiah}

Allah berkata kepada Adam, "Terkutuklah tanah karena engkau" (Kej. 3:17), menurut Hoekema "Inilah kutukan kedua: alam menderita bersama umat manusia; bersama manusia, aiam harus menanggung akibat dosa." 44

Menurut Hoekema, Alkitab menjelaskan akibat kutuk terhadap tanah ini dengan tiga cara. ${ }^{45}$

1. "Dengan bersusah payah engkau akan mencari rezekimu dari tanah seumur hidupmu" (ayt. 17). laki-laki akan mencari rezeki dari tanah dengan kerja yang penuh susah payah. Semenjak kejatuhan, kerja menjadi tidak menyenangkan dan disertai dengan berbagai kesulitan.

2. "Semak duri dan rumput duri yang akan dihasilkannya bagimu" (ayt. 18). Jenisjenis tanaman yang tidak diharapkan mulai bermunculan, sehingga usaha manusia untuk mengolah tanah menjadi lebih sukar daripada sebelumnya. Yang disebutkan di sini memang hanya aspek-aspek kutukan yang berkenaan dengan agrikultural, tapi jelas bahwa akibat-akibat lain harus dimasukkan pula, seperti bencana alam banjir, gempa bumi, dan kuman penyakit, virus serta serangga penyebar penyakit. Calvin menyatakan, "Keseluruhan tatanan alam telah dirusak oleh dosa manusia".

3. "Dengan berpeluh engkau akan mencari makananmu" (ayt. 19). Di sini ditemukan pernyataan ulang dari "bersusah payah" di ayat 17. Kerja keras akan menjadi bagian hidup manusia. 
Jadi, adanya kejahatan alamiah yang dijumpai oleh manusia mempunyai hubungan dengan kejatuhan manusia. Berkhof menekankan, "Sebab oleh karena manusia, maka seluruh ciptaan menjadi sia-sia dan berada di bawah kuasa kecemaran ( $R m$. 8:20-21). ${ }^{\prime 46}$ Tepat untuk mengatakan bahwa kejahatan alamiah adalah akibat dari dosa.

Selain itu, kejahatan alamiah yang pertama yaitu air bah (Kej. 6:5-8; 8:21), merupakan pernyataan penghukuman Allah atas dosa manusia. Ini berarti, akibat dosa bukan hanya merupakan konsekuensi negatif terhadap proses alamiah (Kej. 3:18-19), tetapi juga merupakan bagian dari penghukuman Allah atas dosa manusia. ${ }^{47}$

Akan tetapi, tidak semua proses alam itu membawa penderitaan bagi manusia. Adakalanya proses alam itu bermanfaat bagi manusia, misalnya banjir Sungai Nil. Ini adalah salah satu fakta anugerah Allah yang besar bagi manusia sekalipun telah jatuh ke dalam dosa.

\section{Pemeliharaan Allah (Providence of God)}

\section{Pengertian Istilah}

Istilah "Providensia" berarti pemeliharaan Allah, berasal dari bahasa Latin yaitu provide, dari kata pro (sebelumnya) dan videre (membekali), maka provide berarti menyediakan sebelumnya atau melihat. ${ }^{48}$

Providensia Allah juga dapat dimengerti sebagai pemeliharaan Allah terhadap ciptaan-Nya melalui berbagai proses yang telah ditetapkannya, yang kurang lebih bisa disebut sebagai hukum-hukum alam. Maksudnya adalah pemeliharaan melalui hal-hal yang bersifat alamiah atau wajar, mungkin pula bersifat adikodrati. ${ }^{49}$ Perlu sekali diketahui, bahwa meskipun disebut sebagai hukum alam, hal yang wajar atau alamiah, bahkan dianggap sebagai suatu kebetulan. Tapi Alkitab jelas sekali menyatakan, bahwa semuanya tidak lepas dari pemeliharaan Allah (Mat. 5:45; Maz. 104:14; Ayb. 37:10,12).

Alkitab memberikan banyak bukti bahwa setelah selesai mencipta, Allah masih terus campur tangan atas jalannya sejarah dunia ini. Allah terus menerus memelihara kelangsungan dunia, Ia melindungi semua makhluk-Nya, Ia bertindak dalam segala peristiwa yang terjadi dalam dunia ini, bahkan Allah mengarahkan segala sesuatu pada tujuan akhir yang telah ditetapkan-Nya. Dalam iman Kristen, konsep ini disebut sebagai providensia Allah atau pemeliharaan Allah.

Jadi, ketika Alkitab berbicara tentang pemeliharaan Allah, maka Alkitab memberikan indikasi bahwa pemeliharaan Allah mencakup seluruh aspek hidup manusia di dalam dunia. Karenanya, pemeliharaan Allah juga meliputi keberadaan bangsa-bangsa di dunia (Dan. 4:25; Kis. 17:26), mencakup keberadaan seluruh individu (I Sam. 2:6-8), bahkan mencakup seluruh tindakan bebas manusia (Ams. 16:1; Fil. 2:13; Maz. 76:10). 


\section{Hubungan Pemeliharaan Allah dan Kejahatan}

Telah dibahas bahwa adanya kejahatan dan penderitaan yang dialami manusia saat ini, tidak bisa terlepas bahwa manusia sudah jatuh ke dalam dosa. Dan adanya fakta bahwa setelah selesai mencipta, Allah masih terus campur tangan atas jalannya sejarah dunia ini, akan menimbulkan pertanyaan lain yang mempertanyakan bagaimana hubungan antara campur tangan Allah dengan masuknya dosa ke dalam dunia yang mengakibatkan adanya kejahatan dan penderitaan.

\section{A. Pemeliharaan Allah dan Permulaan Kejahatan: Allah Mengijinkan}

Telah dibahas sebelumnya bahwa Allah bukan pencipta dosa, dalam hal ini Francis Turretin menjelaskan,

This permission is not ethical or moral (which is of right by a relaxation or dispensation of the law, which is opposed to prohibition). In this sense, if God permitted sin, he would also approve it as lawful or just (which is absurd). Rather this permission is physical (which is of fact by a not hindering, which is opposed to effecting). The former regards God as legislator and judge; the latter, however, as the supreme Lord and ruler of the world, governing and regulating the events of the all things according to His will. The former is done by justice when He gives the license to do something; the strength which could actually prevent this or that from being done. ${ }^{50}$

Allah mengijinkan adanya dosa, namun ijin Allah tidak boleh dilihat dalam pengertian etis-moral. Maksudnya, jika Allah mengijinkan kejahatan masuk ke dalam dunia, tidak berarti bahwa Ia juga mengakui kejahatan itu sebagai sesuatu yang benar dan sesua: dengan hukum-Nya. Tetapi ijin Allah lebir kepada pengertian bahwa Allah tidak menghalangi masuknya kejahatan ke dalam dunia ini.

Berkhof menekankan bahwa, "Ketetapan yang berkenan dengan dosa bukanlah ketetapan yang efisien tetapi merupakan ketetapan yang mengijinkan, atau ketetapan untuk membiarkan, dan berbeda dengan ketetapan untuk menghasilkan dosa dengan efisiensi Ailah." ${ }^{\prime \prime 1}$

Keja tuhan manusia ke dalam dosa terjadi pada pemeliharaan Allah yang mengijinkan ini. Karena itu, lebih tepat untuk mengatakan bahwa Allah mengijinkan adanya dosa. Kejahatan dapat masuk ke dalam dunia karena Allah mengijinkan hal itu terjadi.

\section{B. Pemeliharaan Allah dan Perkembangan Kejahatan : Allah Mengarahkan}

Berkaitan dengan pemeliharaan yang mengarahkan ini, Ericson berpendapat, God can also direct $\sin$.That is, while permitting sorne sins to occur, God nonetheless direct them in such a way that good comes out of them. (story of Joseph, Act. 2:36; Rom.1:13-15, 25). God is like a counterpuncher or. perhaps more accurately, like a 
judo expert who redirects the evil efforts of sinful men and satan in such a way that they become the very means of doing good. We must recognize here the amazing nature of divine omnipotence. If God were great and powerful, but not all-powerful, He would lose control of the situation and be unable to accomplish His ultimate purposes. But our omnipotent God is able to allow evil men to do their very worst, and still He accomplishes His purposes. ${ }^{52}$

Jadi, dalam kebijaksanaan dan kemahakuasaan-Nya, Allah mengarahkan kejahatan untuk mencapai tujuan baik-Nya Contonya, dalam kisah Yusuf (Kej.37-50), melalui tindakan kejahatan yang dilakukan oleh saudara-saudaranya, Allah mengarahkan kejahatan tersebut untuk menyelamatkan umat pilihan-Nya (dan Yusuf menyadari hal ini-Kej.50:20). Demikian juga dengan kisah penyaliban Kristus, puncak kejahatan terjadi dalam diri Kristus tetapi Allah mengarahkannya untuk menyelamatkan umat pilihanNya.

Dalam sifatnya yang mengarahkan, pemeliharaan Allah ini dapat dibagi dalam dua bagian:

Pertama, Allah mencegah terjadinya kejahatan. dalam kisah Abimelekh (Kej.20:6), Allah berintervensi secara langsung mencegahnya melakukan dosa menghampiri Sara. Daud juga berdoa agar Allah melindunginya dari kejahatan (Maz.19:13-14). sebelum seseorang sampai melakukan dosa, kadangkala Allah mencegah peristiwa tesebut. Ericson mengatakan, "God prevent sin. at times He deters or precludes people from performing certain sinful acts." ${ }^{\prime 3}$

Kedua, Allah membatasi. Pengontrolan Allah terhadap dosa dapat terlihat dalam batasan jangkauan dosa tersebut. Kisah Ayub menunjukkan hal ini. selain itu, dalam I Korintus 10:13 dikatakan bahwa pencobaan yang dialami manusia tidak melebihi kekuatannya. Istilah 'batas' ini harus dimengerti dari sudut pemeliharaan Allah yang mengarahkan dengan bijaksana dan dengan kemahakuasaan-Nya. Dalam hal ini, Ericson menjelaskan,

God can limit sin. There are times when he does not prevent evil deeds, but nonetheless restrains the extent or effect of what evil men and the devil and his demon can do. A prime example is the case of Job.God permitted satan to act, but limited what he could do. Job 1:12, Ps.124:1-3; I Cor.10:13. Even when

God permits sin to occur, he imposes liits beyond which it cannot go.

Jadi, meskipun pada dasarnya manusia adalah manusia berdosa tapi natur tesebut tidak tereskpresi dalam bentuk tindakan kejahatan karena Allah mencegahnya. Dan di lain sisi, saat natur berdosa tersebut terekspresi dalam tindakan kejahatan, Allah membatasinya dalam jangkauan-Nya.

Ketika mengatakan Allah mengarahkan kejahatan pada kebaikan, harus diingat bahwa ini tidaklah berarti kejahatan itu merupakan suatu perbuatan baik. Kejahatan 
adalah dosa dan harus dihukum, namun karena kebijaksanaan dan kemahakuasaan Allah, Ia dapat memakainya dan mengarahkannya untuk menggenapkan apa yang telah direncanakan-Nya.

\section{Hubungan Kejahatan dan Maksud Allah}

Fakta adanya kejahatan dan penderitaan tidak terlepas dari pemeliharaan Allah, memiliki implikasi bahwa pasti ada suatu maksud Allah di balik kejahatan dan penderitaan yang dialami manusia tersebut.

\section{A. Kejahatan Sebagai Sarana Penghukuman Allah}

Penghukuman ini berkaitan erat dengan sifat kekudusan dan keadilan Allah. Sifat Allah ini tidak dapat mentolerir kejahatan yang dilakukan oleh manusia, untuk itulah sarana penghukuman Allah harus dilakukan. Morris menekankan, "There is really no such things as the 'innocent' suffering. Since all have sinned and come short of the glory of God (Rom.3:23), there is no one who has the right to freedom from God's wrath on the basis of his own innocence." 54

Penghukuman harus dinyatakan bagi seluruh umat manusia oleh karena di hadapan Allah tidak ada satu orang pun benar. Hanya Yesus satu-satunya manusia yang 'innocent' - tidak bersalah, harus menderita, disalibkan dan mati karena keberdosaan manusia. Jika Kristus pun mengalami penderitaan seperti itu, tentunya tidak ada alasan bagi manusia untuk menuduh Allah dan mempertanyakan mengapa manusia harus menderita.

Memang benar bahwa kadangkala seseorang harus menderita di tangan orag lain tanpa ada hubungan atau suatu kesalahan tertentu dengan orang yang membuatnya

"Dalam tingkat horisontal hal ini dapat dibenarkan, tapi dalam tingkat vertikal jelas tidak mungkin. Maksudnya, ketika seseorang menderita, maka dalam hubungannya dengan Allah (vertikal) tidak ada istilah ketidakadilan. Hal ini dikarenakan semua manusia di hadapan Allah berada dalam status orang bersalah. Tapi dalam hubungannya dengan sesama manusia (horisontal), bisa saja dikatakan bahwa penderitaan yang diderita seseorang tidak adil. Ini dikarenakan orang yang menderita tersebut tidak melakukan kesalahan apa-apa terhadap orang atau alam yang membuatnya menderita." ${ }^{\prime 25}$

Namun perlu ditegaskan bahwa tidak selalu ada korelasi 'langsung' antara dosa dengan penderitaan. Hal ini ditegaskan oleh Kristus dalam Yoh.9:1-3. Kadangkala 
seseorang menderita bukan karena derajat dosa yang telah diperbuatnya sedemikian besar, tetapi lebih kepada fakta akan sifat kehadiran dosa yang universal.

\section{B. Kejahatan Sebagai Sarana Pendidikan Allah}

Alkitab juga mencatat bahwa penderitaan adalah sarana pendidikan dan disiplin Allah dalam mendidik dan melatih umat-Nya. Newport menegaskan,

This solution is associated with covenant idea in the Old Testament and with the New Testament description of God as heavenly Father... God disciplines his people, collectively and individually, that they may be brought closer to him. The purpose of God's discipline is often to teach a lesson, to train and to mature his children through suffering. ${ }^{56}$

Jadi, Allah bukan saja sebagai seorang hakim yang adil tapi juga sebagai seorang ayah yang mendidik anak-anak-Nya. Allah manggunakan penderitaan untuk mendidik orang percaya sehingga mereka terus bertumbuh semakin dekat dengan Allah (Yak.1:34; I Pet.5:10). Penderitaan sebagai kesempatan untuk mencontohi Kristus (I Pet.3:17-18; 2:23; Mat.10:24-25), penderitaan sebagai tantangan bagi orang percaya untuk bertumbuh dan bukan untuk jatuh dalam dosa (Yak.1:1-12), penderitaan juga sebagai sarana pembuktian kemurnian iman (I Pet.1:6-7), dan Feinberg menyebut penderitaan sebagai sarana pengudusan Allah.

\section{Kejahatan Sebagai Sarana Penyingkapan Diri Allah}

Penderitaan sebagai sarana penyingkapan diri Allah maksudnya adalah kemahakuasaan dan kemuliaan Allah dapat menjadi nyata melalui apa yang dikerjakanNya di dalam penderitaan, misalnya melalui m:jizat penyembuhan yang dilakukanNya.

Selain itu, melalui penderitaan, orang percaya menjadi dekat dengan Allah dalam hal melihat kedaulatan dan keagungan Allah yang belum pernah dilihat sebelumnya. Feinberg mengatakan, "Some times our view of God is too small, and God correts that by sending afflictions and than proving Himself to be the allpowerful One in our behalf." ${ }^{\prime 57}$ Penderitaan akan membuat orang percaya semakin intim dengan Allah. Sama dengan Ayub yang akhirnya menjadi lebih dekat dengan Allah setelah mengenal-Nya dengan lebih baik (Ay.42:2-4). Newport menegaskan hal yang sama, "The fact that many have found the true glory of God in times of great suffering confirms the truth of the Biblical implication." 58

\section{Kejahatan dan Keterbatasan Manusia}

Meskipun Alkitab memberikan beberapa jawaban akan maksud Allah melalui penderitaan, namun perlu diingat bahwa kejahatan juga merupakan satu misteri bagi 
manusia. Sebagai makhluk ciptaan yang terbatas dan tercemar oleh dosa, manusia tidak akan pernah mungkin memahami keberadaan kejahatan beserta maksud Allah dengan tuntas. Newport menegaskan, "The Bible often confesses the mistery of suffering. It is not strange that such is the case, for in many ways the problem of evil is beyond theoretical explanation." 59

Yang harus dikerjakan orang percaya adalah bagaimana bersikap dengan tepat terhadap penderitaan. Orang percaya harus tetap mempercayai kebaikan dan kebijaksanaan Allah, di tengah-tengah keterbatasan akal manusia untuk memahami maksud Allah. Roma 5:3-5 mengingatkan agar orang percaya bermegah dalam penderitaan. Hal ini dikarenakan ada pengharapan yang tidak mengecewakan orang percaya, yaitu pengharapan dari Allah sendiri.

Kitab Ayub 13:15 mencatat sikap percaya Ayub yang mutlak pada kedaulatan Allah. Sproul menjelaskan bahwa Allah meminta Ayub agar percaya dengan suatu iman yang implisit. Iman yang implisit beda dengan iman yang buta. Iman yang implisit adalah suatu iman dengan penglihatan yang disinari oleh suatu pengetahuan akan sifat Allah. ${ }^{60}$ Kisah Ayub mengajarkan pada manusia untuk percaya kepada Allah dan belajar bagaimana seharusnya hidup sebagai orang percaya di tengah-tengah fakta adanya kejahatan. Seperti penekanan Newport, "The problem of evil is not solved for Job, but he learns how to live with it. He learns that he may well trust God in the mistery of evil, for he has learned to trust God and his goodness and wisdom in the clarities of creation." ${ }^{61}$

Namun seringkali karena keterbatasan manusia untuk mengerti maksud Allah sehingga kelihatannya penderitaan itu tidak mempunyai tujuan sama sekali. Karena itulah dengan konsep pemeliharaan Allah maka tidak ada istilah 'accident' (suatu kecelakaan atau kebetulan), yang ada hanyalah 'incident' (suatu peristiwa). Allah campur tangan di dalam sejarah umat manusia. Maka dengan demikian, ketika orang percaya menghadapi kejahatan dan penderitaan, respon yang muncul dari orang percaya berbeda dengan respon dari orang yang tidak percaya. Orang yang tidak percaya akan memberontak dan menuduh Allah. Sebaliknya, orang percaya tetap percaya dan berpengharapan kepada Allah.

\section{KESIMPULAN}

Kehidupan ini memang tidak bisa lepas dari kejahatan, yang bilamana kejahatan tersebut mendatangkan penderitaan maka penderitaan itu merupakan problema kejahatan. Masalah kejahatan ini terbagi menjadi dua, yaitu kejahatan moral yang 
dilakukan oleh oknum bermoral yang dalam hal ini adalah manusia, dan kejahatan alamiah atau fisik.

Fakta dari adanya kejahatan dan penderitaan di dalam dunia ini bermuara dari kejatuhan manusia pertama ke dalam dosa, "Sebab oleh karena manusia maka seluruh ciptaan menjadi sia-sia dan berada di bawah kuasa kecemaran (Roma 8:20-21)." Kejatuhan manusia ke dalam dosa merupakan kejahatan moral yang pertama yang kemudian diikuti dengan kejahatan moral lainnya. Kejatuhan ini pun mengakibatkan konsekuensi negatif terhadap proses alamiah, sekalipun tidak semua proses alam itu membawa penderitaan bagi manusia. Adakalanya proses alam itu bermanfaat bagi manusia.

Meskipun manusia menjumpai adanya fakta kejahatan dan penderitaan, namun Alkitab mencatat bahwa adanya kejahatan dan penderitaan tidak lepas dari pemeliharaan Allah, dan di balik semuanya itu Allah mempunyai maksud tertentu.

Allah tidak boleh dianggap sebagai penyebab kejahatan dan penderitaan, tetapi Allah mengijinkan kejahatan dan penderitaan itu ada, dan Allah di dalam pemeliharaanNya berkenan mengarahkan kejahatan dan penderitaan tersebut untuk mencapai maksud dan tujuan-Nya. Allah turut bekerja dalam segala sesuatu untuk mendatangkan kebaikan bagi mereka yang mengasihi-Nya (Roma 8:28). Ini bukanlah berarti kejahatan adalah sesuatu yang baik, namun Allah mengarahkannya untuk mencapai tujuan baik-Nya.

Maksud Allah mengijinkan kejahatan dan penderitaan ada dalam dunia ini adalah sebagai sarana penghukuman Allah, sebagai sarana pendidikan Allah dan sebagai sarana penyingkapan diri Allah.

Sekalipun Alkitab memberikan fakta adanya pemeliharaan Allah, namun manusia tidak akan pernah bisa mengerti secara sempurna oleh karena keterbatasannya; mengapa Allah mengijinkan adanya kejahatan dan penderitaan, dan apa maksud Allah di balik kejahatan dan penderitaan tersebut. Jelaslah bahwa masalah kejahatan dan penderitaan tetaplah suatu misteri bagi manusia.

Akan tetapi, meskipun masalah kejahatan dan penderitaan adalah suatu misteri, namun ketika orang percaya menghadapi kejahatan dan penderitaan, mereka harus mempercayai adanya kebaikan dan kebijaksanaan Allah di tengah-tengah keterbatasan akal manusia untuk memahami maksud Allah.

Hendaknya orang percaya bermegah di dalam penderitaan (Rom.5:3-5). Hal ini dikarenakan ada pengharapan yang tidak mengecewakan bagi orang percaya, yaitu pengharapan dari Allah sendiri. Allah memiliki campur tangan atas segala sesuatu di dalam kebaikan, kebijaksanaan, kemahatahuan dan kemahakuasan- Nya.yang tak terpahami oleh manusia. Inilah pemeliharaan Allah atas manusia di tengah-tengah fakta adanya kejahatan dan penderitaan. 


\section{Endnotes:}

${ }^{1}$ John M. Frame, Apologetika Bagi Kemuliaan Allah, (Surabaya: Penerbit Momentum, 2000), 192.

${ }^{2}$ John M. Echols, Kamus Inggris-Indonesia, (Jakarta: PT Gramedia, 1996), 221.

${ }^{3}$ R.C Sproul, Mengapa Percaya (Terjemahan dari Reason to Believe), (Malang: SAAT, 1995), 123.

${ }^{4}$ Ibid.,

s Ibid.

${ }^{6} \mathrm{Ibid}, 117-118$.

${ }^{7} \mathrm{Kita}$ tidak menerima adanya kejahatan metafisik akibat keterbatasan/ketidaksempurnaan manusia. Konsep ini menyalahkan Tuhan yang telah menciptakan manusia sebagai manusia terbatas, sehingga manusia berdosa. Hanya Allah yang sempurna.

${ }^{8}$ Kamus Besar Bahasa Indonesia, (Departemen Pendidikan dan Kebudayaan, 1994), 665.

9 John M. Frame, Apologetika Bagi Kemuliaan Allah, (Surabaya, Penerbit Momentum, 2000), 123.

${ }^{10} \mathrm{Ibid}, 123$.

11 lbid, 125.

${ }^{12}$ Kamus Besar Bahasa Indonesia, Departemen Pendidikan dan Kebudayaan, 1988.

${ }^{13}$ John M. Frame, Apologetika Bagi Kemuliaan Allah, 126.

${ }^{14}$ K. Bertens, Etika, (Jakarta: PT Gramedia, 1994), 150.

${ }^{15}$ Ibid, 151, 153.

${ }^{16}$ Obyektif yang dimaksudkan adalah berlaku untuk semua orang, di mana saja dan kapan saja.

${ }^{17}$ C. S. Lewis, The Problem of Pain, (London: Haper Colins Publishing, 1977), 30.

${ }^{18}$ Van De Beek, Why-On the Suffering, Guilt, and God, (Grand Rapids, MI: Eerdmans, 1990), 16.

${ }^{19}$ Ibid, 16.

${ }^{20}$ Hendry M..Morris, The Bible Has The Answer, (Netley, New Jersey: The Craig Press, 1971), 178.

21 William Dyrness, Tema-tema Dalam Perjanjian Lama, (Malang: Penerbit Gandum Mas, 2001), 88-89.

${ }^{22}$ Louis Berkhof, Teologi Sistematika-Doktrin Manusia, (Jakarta: LRII, 1994), 108.

${ }^{23}$ Ibid, 107.

${ }^{24}$ Bagi penulis, sebenarnya istilah "kejahatan alamiah" kurang tepat, karena kata kejahatan itu sendiri mempunyai pengertian melanggar firman Allah, dan alam tidak melakukan pelanggaran ini. Alam menjadi seperti saat ini oleh karena ulah manusia yang berbuat dosa (Kej. 3:17-19; 8:21-22). Penulis lebih menyetujui istilah "akibat dosa" untuk menunjuk kepada peristiwa-peristiwa alam. Lebih lagi, istilah "kejahatan alamiah" tidak hanya terbatas pada peristiwa-peristiwa alam saja. Tapi cakupannya jauh lebih luas. Namun penulis tetap memilih untuk menakai istilah ini untuk membedakannya dengan kejahatan moral yang dilakukan manusia secara langsung. Jadi, penggunaan istilah ini mendapat pengertian tambahan sebagai akibat dari dosa manusia. 
${ }^{25}$ Beberapa teori filsafat tersebut adalah: 1) Teori Dualistik, percaya bahwa kejahatan sama kekalnya dengan kebaikan, dan tubuh (materi) mewakili prinsip-prinsip yang jahat. 2) Teori yang menekankan bahwa dosa hanyalah kurangnya hal-hal penting dalam hidup (Leibniz). 3) Teori bahwa dosa adala ilusi (Spinoza). 4) Teori bahwa dosa adalah kebutuhan akan kesadaran Allah, berkaitan dengan natur inderawi manusia (Schleirmacher). 5) Teori bahwa dosa sebagai hilangnya percaya kepada Allah dan perlawanan terhadap kerajaan-Nya, dalam kaitan dengan kebodohan (Ritschl). 6) Teori bahwa dosa adalah ketamakan (Mueller dan A. H. Strong). 7) Teori bahwa dosa adalah pertentangan dari kecenderungan natur manusia yang lebih rendah menuju pada kesadaran moral yang semakin berkembang (Tennant). Lihat Berkhof, Teologi Sistematika, hal. 101-107.

${ }^{26}$ Ibid, 107.

${ }^{27}$ Anthony A. Hoekema, Manusia: Ciptaan Menurut Gambar Allah, (Surabaya: Penerbit Momentum, 2003), 157.

${ }^{28}$ Bruce Milne, Mengenali Kebenaran, (Jakarta: BPK Gunung Mulia, 1993), 145.

${ }^{29}$ Berkhof, Teologi Sistematika, 84.

${ }^{30}$ Anthony A. Hoekema, Manusia: Ciptaan Menurut Gambar Allah, 157.

${ }^{31}$ Berkhof, Teologi Sistematika, 85.

${ }^{32}$ Anthony A. Hoekema, Manusia: Ciptaan Menurut Gambar Allah, 158.

${ }^{33}$ Berkhof, Teologi Sistematika, 85.

${ }^{34}$ Anthony A. Hoekema, Manusia: Ciptaan Menurut Gambar Allah, 157.

${ }^{35}$ Berkhof, Teologi Sistematika, 86.

${ }^{36}$ Anthony A. Hoekema, Manusia: Ciptaan Menurut Gambar Allah, 182.

${ }^{37}$ Berkhof, Teologi Sistematika,136-137.

${ }^{38}$ Kata "kesalahan" menyatakan hubungan dosa terhadap keadilan, hubungan dosa dengan hukuman dosa, istilah "kesalahan" dibicarakan dalam arti "reatus poenae", yang berarti pelaksanaan hukuman atau kewajiban untuk membayar pemuasan atas keadilan Allah bagi pelanggaran atas hukum yang dilakukan manusia.

${ }^{39} \mathrm{Kata}$ ini mencakup kerusakan total dan ketidakmampuan total. Istilah ini menyatakan bahwa kecemaran dalam diri manusia telah meliputi seluruh aspek hidupnya, sehingga ia tidak mampu untuk melakukan sesuatu yang baik Istilah kekotoran asal akhirnya menunjukkan bahwa sifat jangkauan dari dosa itu telah menyeluruh (universal).

${ }^{40}$ Van De Beek, Why-On the Suffering, Guilt, and God, 137-138.

${ }^{41}$ Berkhof, Teologi Sistematika, 165-169.

42 Van De Beek, Why-On the Suffering, Guilt, and God, 21. 
${ }^{43}$ John F. McArthur Jr., Hamartiologi:Doktrin Alkitab Tentang Dosa, (Malang: Gandum Mas, 2000), 98.

${ }^{44}$ Anthony A. Hoekema, Manusia: Ciptaan Menurut Gambar Allah, 176.

45 lbid, 175-177.

${ }^{46}$ Berkhof, Teologi Sistematika, 167.

${ }^{47}$ Penjelasan lain dapat dilihat dalam bagian Defenisi Dosa dan Hukuman dan Jangkauan Dosa (Penderitaan-penderitaan dalam hidup).

${ }^{48}$ Henk ten Napel, Kamus Teologi Inggris-Indonesia, (Jakarta: BPK Gunung Mulia, 1996), 257.

${ }^{49}$ William Dyrness, Tema-tema dalam Teologi Perjanjian Lama, (Malang: Gandum Mas, 2001)5758.

${ }^{50}$ Francis Turretin, Institutes of Elenctic Theology Vol.One.Trans. George Musgrave Giger, Ed. James T. Dennison, Jr. Philipsburg, (New Jersey: 1992), 516.

${ }^{51}$ Berkhof, Teologi Sistematika, 196.

${ }^{52}$ Millard. J Ericson, Christian Theology, (Grand Rapids, MI: Baker Book House), 1985.

${ }^{53}$ Ibid, 399.

${ }^{54}$ Hendry M. Morris, The Bible Has The Answer, 178.

${ }^{55}$ R C. Sproul, Hai Maut Di manakah Sengatmu?, (Jakarta: BPK Gunung Mulia, 1991),33.

${ }^{56}$ John P. Newport, Life's Ultimate Question, (USA, Word Publishing, 1989), 231.

57 J S. Feinberg, Many Faces of Evil, (Grand Rapids, MI: Zondervan Publishing, 1979), 343.

${ }^{58}$ John P. Newport, Life

's Ultimate Question, 232.

${ }^{59}$ Ibid, 233.

${ }^{60}$ R C. Sproul, Hai Maut Di manakah Sengatmu?, (Jakarta: BPK Gunung Mulia, 1991),38.

${ }^{61}$ John P. Newport, Life's Ultimate Question, 233. 


\section{DAFTAR PUSTAKA}

Beek, Van De. Why-On the Suffering, Guilt, and God, Grand Rapids, MI: Eerdmans, 1990. Berkhof, Louis. Teologi Sistematika-Doktrin Manusia, Jakarta: LRII, 1994.

Bertens, K. Etika, Jakarta: PT Gramedia, 1994.

Dyrness, William. Tema-tema Dalam Perjanjian Lama, Malang: Penerbit Gandum Mas, 2001.

Echols, John M. Kamus Inggris-Indonesia, Jakarta: PT Gramedia, 1996.

Ericson, Millard J. Christian Theology, Grand Rapids, MI: Baker Book House.

Feinberg, J. S. Many Faces of Evil, Grand Rapids, MI: Zondervan Publishing, 1979.

Frame, John M. Apologetika Bagi Kemuliaan Allah, Surabaya: Penerbit Momentum, 2000.

Hoekema, Anthony A. Manusia: Ciptaan Menurut Gambar Allah, Surabaya: Penerbit Momentum, 2003.

Kamus Besar Bahasa Indonesia. Departemen Pendidikan dan Kebudayaan, 1994.

Lewis, C. S. The Problem of Pain, London: Haper Colins Publishing, 1977.

McArthur, Jr., John F., Hamartiologi:Doktrin Alkitab Tentang Dosa, Malang: Gandum Mas, 2000.

Milne, Bruce. Mengenali Kebenaran, Jakarta: PT BPK Gunung Mulia, 1993.

Morris, Hendry M. The Bible Has The Answer, Netley, New Jersey: The Craig Press, 1971. Napel, Henk Ten. Kamus Teologi Inggris-Indonesia, Jakarta: PT BPK Gunung Mulia, 1996. Newport, John P. Life's Ultimate Question, USA, Word Publishing, 1989.

Sproul, R.C. Mengapa Percaya (Terjemahan dari Reason to Believe), Malang: SAAT, 1995. Sproul, R. C. Hai Maut Di manakah Sengatmu?, Jakarta: PT BPK Gunung Mulia, 1991. Turretin, Francis. Institutes of Elenctic Theology Vol. One. Trans. George Musgrave Giger, Ed. James T. Dennison, Jr. Philipsburg, New Jersey: 1992. 